\title{
An Initial Life Cycle Assessment of Rare Earth Oxides Production from
}

\author{
Ion-Adsorption Clays \\ Ehsan Vahidi ${ }^{1,2}$, Julio Navarro ${ }^{3}$, Fu Zhao ${ }^{1,2,3, *}$ \\ ${ }^{1}$ Division of Environmental and Ecological Engineering, Purdue University, West Lafayette, IN, \\ USA \\ ${ }^{2}$ Ecological Science and Engineering Interdisciplinary Graduate Program, Purdue University, \\ West Lafayette, IN, USA \\ ${ }^{3}$ School of Mechanical Engineering, Purdue University, West Lafayette, IN, USA
}

\begin{abstract}
Rare earth elements (REEs) have found applications in the aerospace, automotive, consumer electronics and lighting industries, among others. A special class of REEs known as heavy rare earths (HREEs) is of particular importance to energy applications. With the growing clean energy technologies incorporating HREEs, it is valuable to examine their environmental emissions and energy requirements. Currently, extraction of HREEs is mainly carried out in China, where they are extracted mainly via open pit mining of bastnasite and/or monazite and leaching of ion-adsorption clays. Leach mining varies significantly from open pit mining technique in that the ores have much lower REE content but REEs stay as cations thus there is no need for physical and chemical beneficiation. To date limited life cycle assessment (LCA) studies have been done on REEs production and all of them are for the bastnasite/monazite route. This paper presents the first LCA of in-situ leach mining of REEs from ion adsorption clays in southern China. The function unit was defined as production of $1 \mathrm{~kg}$ of mixed rare earth oxides (REOs) of purity $92 \%$. Ecoinvent 3.0 database was adopted for inventory analysis with material and energy flow information gathered from Chinese literature. To facilitate the use of results in U.S. and EU, TRACI and ILCD in SimaPro 8 were used for environmental impact assessment and cumulative energy demand was also considered as one additional category. The results showed that the environmental impacts for REOs derived from ion adsorption clays are similar in

\footnotetext{
* Corresponding author. Tel.: +1 765 4946637; fax: +1 7654940539.

E-mail address: fzhao@purdue.edu (Fu Zhao).
} 
categories such as global warming and cumulative energy demand, but differs significantly in categories of eutrophication and acidification. Since the content of high value HREEs is much higher in ion adsorption clays, when economic value based allocation is used individual REO from in situ leaching has lower environmental impacts across all categories considered. With estimates of HREEs derived from ion-adsorption clays accounting for approximately $35 \%$ of the Chinese output, this LCA is a step towards getting a full understanding of the true environmental impact of technologies incorporating HREEs.

Keywords: Rare earth elements, Ion-Adsorption clays, Life cycle assessment, in situ leaching

\section{Introduction}

Rare earth elements (REEs) are a body of 17 elements composed of the lanthanide group, atomic numbers (57-71), along with scandium (Sc, 21) and yttrium (Y, 39). REEs are typically grouped in two different categories: light rare earth elements (LREEs, atomic numbers 57-63), and heavy rare earth elements (HREEs, atomic numbers 64-71 plus yttrium 39) (Hurst, 2010). While it is included with the REEs, scandium does not fall into the category of LREEs or HREEs (Jordens et al., 2013). Due to their unique physical and chemical properties, REEs find wide applications in electronic, optical, magnetic and catalytic products (Bradsher, 2009; Greenfield et al., 2013; Chanceral et al., 2015).

REEs are widely utilized in industrial sectors such as petroleum, agriculture, and metallurgy while they are becoming critical in many high-tech applications such as wind turbines, fluorescent lights, mobile phones, liquid crystal screen televisions, hybrid cars, and military systems (Song and Hong, 2010a,b; Adibi et al., 2014). Their importance in the growing field of green energy technology and high energy efficiency applications have led to many governments to classify some REEs as "critical materials" (Bauer et al., 2010; Tse, 2011; United States Geological Survey, 2014; Wubbeke, 2013; Papangelakis and Moldovenau, 2014), and strategies such as material substitution, diversifying supplies, and recycling have been proposed (Bauer et al., 2011; Machacek et al., 2015; Wu et al., 2014; Ferella et al., 2016) . 
Extraction of REEs is mainly carried out in China (Hellman and Duncan, 2015), where they are extracted via either open-pit mining of bastnasite and monazite (mainly in the Bayan Obo region in Inner Mongolia) or leaching of ion-adsorption clays (mainly in Southern China) (Kanazaw and Kamitani, 2006). China is currently producing over 95\% of the world's total supply from its mines and this dominance may be a cause for concern because growing demand in China for REEs and some export restrictions would negatively affect United States and Europe as major consumers and importers of rare-earth products (Adachi et al., 2010; Kynicky et al., 2012; Jordens et al., 2013; USGS, 2014). According to China's Ministry of Environmental Protection (MEP, 2009) and the Chinese Society of Rare Earths (CSRE, 2002), China has 52 million tons of proved industrial reserves ${ }^{2}$. Compared with bastnasite and monazite, ion adsorption clays only account for a much smaller percentage of total REEs reserve of China (3\% vs. $84 \%$ ) (Schuler et al., 2011).

Table 1. REE content in different ores.

\begin{tabular}{|c|c|c|c|c|c|c|c|c|c|}
\hline \multirow{2}{*}{$\begin{array}{c}\text { Ore } \\
\text { REO }\end{array}$} & \multicolumn{2}{|c|}{$\begin{array}{c}\text { Bayan Obo }^{1} \\
(800 \text { million metric } \\
\text { tons; } 6 \text { wt } \% \text { REO) }\end{array}$} & \multirow{2}{*}{$\begin{array}{c}\begin{array}{c}\text { Mountain Pass }^{2} \\
(3.3 \text { million metric } \\
\text { tons; } 7.7 \mathrm{wt} \% \text { REO) }\end{array} \\
\text { Bastnasite }\end{array}$} & \multicolumn{6}{|c|}{$\begin{array}{c}\text { Ion-adsorption clays }{ }^{3} \\
(130 \text { million metric tons; } 0.05-0.2 \text { wt } \% \text { REO) }\end{array}$} \\
\hline & Bastnasite & Monazite & & $\begin{array}{c}\text { Site } \\
\text { A }\end{array}$ & $\begin{array}{c}\text { Site } \\
\text { B }\end{array}$ & $\begin{array}{c}\text { Site } \\
\text { C }\end{array}$ & $\begin{array}{c}\text { Site } \\
\text { D }\end{array}$ & $\begin{array}{c}\text { Site } \\
\text { E }\end{array}$ & $\begin{array}{c}\text { Site } \\
\text { F }\end{array}$ \\
\hline $\mathrm{La}_{2} \mathrm{O}_{3}$ & 27.0 & 23.4 & 33.2 & 2.1 & 20.0 & 8.5 & 29.8 & 27.4 & 13.1 \\
\hline $\mathrm{CeO}_{3}$ & 50.0 & 45.7 & 49.1 & 12.8 & 1.3 & 1.1 & 7.2 & 3.1 & 1.3 \\
\hline $\mathrm{Pr}_{6} \mathrm{O}_{11}$ & 5.0 & 4.2 & 4.3 & 1.1 & 5.5 & 1.9 & 7.4 & 5.8 & 4.9 \\
\hline $\mathrm{Nd}_{2} \mathrm{O}_{3}$ & 15.0 & 15.7 & 12.0 & 5.1 & 26.0 & 7.4 & 30.2 & 18.7 & 13.4 \\
\hline $\mathrm{Sm}_{2} \mathrm{O}_{3}$ & 1.1 & 3.1 & 0.8 & 3.2 & 4.5 & 2.6 & 6.3 & 4.3 & 4.0 \\
\hline $\mathrm{Eu}_{2} \mathrm{O}_{3}$ & 0.2 & 0.1 & 0.1 & $<0.3$ & 1.1 & 0.2 & 0.5 & $<0.3$ & 0.2 \\
\hline $\mathrm{Y}_{2} \mathrm{O}_{3}$ & 0.3 & 3.1 & 0.1 & 62.9 & 25.9 & 49.9 & 10.1 & 26.4 & 41.7 \\
\hline $\mathrm{Gd}_{2} \mathrm{O}_{3}$ & 0.4 & 2.0 & 0.2 & 5.7 & 4.5 & 6.8 & 4.2 & 4.4 & 5.1 \\
\hline $\mathrm{Tb}_{2} \mathrm{O}_{3}$ & Trace & 0.1 & 0.02 & 1.1 & 0.6 & 1.4 & 0.5 & 0.7 & 1.2 \\
\hline $\mathrm{Dy}_{2} \mathrm{O}_{3}$ & Trace & 1.0 & 0.03 & 7.5 & 4.1 & 8.6 & 1.8 & 4.0 & 7.1 \\
\hline $\mathrm{Ho}_{2} \mathrm{O}_{3}$ & Trace & 0.1 & $<0.01$ & 1.6 & $<0.3$ & 1.4 & 0.3 & 0.5 & 1.1 \\
\hline $\mathrm{E}_{\mathrm{r} 2} \mathrm{O}_{3}$ & 1.0 & 0.5 & $<0.01$ & 4.3 & 2.2 & 4.2 & 0.9 & 2.3 & 3.1 \\
\hline $\mathrm{Tm}_{2} \mathrm{O}_{3}$ & Trace & 0.5 & $<0.01$ & 0.6 & $<0.3$ & 1.2 & 0.1 & 0.3 & 1.5 \\
\hline $\mathrm{Yb}_{2} \mathrm{O}_{3}$ & Trace & 0.5 & $<0.01$ & 3.3 & 1.4 & 4.1 & 0.6 & 2.0 & 2.0 \\
\hline $\mathrm{Lu}_{2} \mathrm{O}_{3}$ & Trace & 0.1 & $<0.01$ & 0.5 & $<0.3$ & 0.7 & 0.1 & $<0.3$ & 0.5 \\
\hline
\end{tabular}

${ }^{1}$ Schuler et al. (2011) ${ }^{2}$ Gupta \& Krishnamurty (2005) ${ }^{3}$ Shi (2009)

2 "The part of the reserve base which could be economically extracted or produced at the time of determination" (USGS, 2008). 
However, ion adsorption clays have different REE content from that of bastnasite and monazite. As shown in Table 1, for ion adsorption clays REE distribution varies significantly from location to location, but they all seem to have much higher content of some highly valuable HREEs than bastnasite and monazite. In addition, as the name implies, REEs present in ion adsorption clays are in the form of trivalent cations adsorbed on kaolin, which brings the relative ease of extraction (i.e., near the surface and unconsolidated).

Due to these reasons, ion adsorption clays represent an important source of REEs, especially HREEs (Chakhmouradian and Wall, 2012; Walters et al., 2011). In fact, approximately 35\% of Chinese production of REEs is coming from ion-adsorption clays (Papangelakis and Moldoveanu, 2014; Yang et al., 2013). Although REEs are critical to many clean energy technologies, the mining, processing, and production of REEs require large energy and material consumption while generating significant air/water emissions and solid wastes. In fact, environmental damage is one of the major reasons cited by Chinese government for imposing export quota.

As the clean energy technology market grows, REEs demand is expected to increase (Binnemans et al., 2013; Hurst, 2010). This calls for a comprehensive examination of the environmental impacts associated with REEs (Li et al., 2014; Liao et al. 2014). To date the most widely used methodology for evaluating the environmental performance of a product or process is life cycle assessment, which holistically takes into consideration of resources consumption and environmental releases along all the life cycle stages (Guinée, 2002).

There have been many reports and studies on the environmental damages caused by the air or water emissions as well as solid wastes from REEs production. However, most of these studies only cover a small portion of the REE life cycle. LCA studies on REEs are very limited and all studies are for the processing of bastnasite (at Mountain Pass, CA) or bastnasite-monazite (at Bayan-Obo, China) (See Navarro and Zhao, 2014 for a review). The datasets in the Ecoinvent database are the first investigation on rare earth oxides where environmental impacts of the Bayan Obo pathway is examined (Althaus et al., 2007). The Bayan Obo pathway was also examined by Koltun and Tharumarajah (2014) where a two-step allocation procedure was 
proposed to deal with the iron/REE co-mining issue. Moreover, Sprecher et al. (2014) conduct an LCA on $\mathrm{NdFeB}$ magnets, which covers all the process steps involved from ore mining to $\mathrm{Nd}$ metal production using Ecoinvent database.

All of the studies discussed above are based on Mountain Pass production data from 1990s or information from Chinese literature on Bayan Obo pathway or a combination. For many process steps, no information is available and surrogates are commonly used. For example, mining of REE bearing ores is approximated by open pit mining of iron ores. Both mass based and revenue based allocation have been adopted to deal with the multi-products issues associated with several REE processing steps. It has also been pointed out that better environmental impact assessment method or indicators may be needed for REE production (Adibi et al., 2014).

While there have been an increasing number of investigations focused on the LCA of REO production from bastnasite and monazite, no LCA study has been attempted for the mining and processing of ion adsorption clay and to the best of our knowledge, this is the first study to assess LCA of rare earth oxides production from ion-adsorption clays, which are important sources of many HREEs critical to energy applications.

\section{In-situ leaching of ion adsorption clays}

Ion-adsorption clays are also commonly known as weathered clays, and are formed from a process unique to certain areas of the world. Under the effect of physical, chemical and biological factors, the rare earth enriched parent rocks (e.g., granite) can have rare earth minerals dissolved gradually and enter water in the form of rare earth ions. When the solution permeates downwards through pores, rare earth ions are adsorbed by the clay minerals such as kaolin (Yang et al., 2013; Zhao et al., 2001; Charles et al., 2013).

Conditions for occurrence include prolonged weathering with limited erosion, and the existence of a crust of high alumino-silicate clay to adsorb rare earth ions (Gupta and Krishnamurthy, 2005: Moldovenau and Papangelakis, 2012). Worldwide the reserve of ion adsorption clays is limited (Zou et al., 2014), and REO concentration is usually between 0.05 and $0.2 \%$ (Golev, 2014; Kanazaw and Kamitani, 2006; Xiao et al., 2003a). Figure 1 presents a diagram of an in-situ 
leaching mining site showing the different soil layers. The completely weathered layer contains the highest concentration of REOs.

To extract REEs from ion-adsorption clays, there are different types of leaching methods that have been applied, e.g. heap, tank/pool, and in-situ leaching methods (Yang et al., 2013). Through these leaching methods, the REEs can be released into the solution by ion exchange mechanism (Chi et al., 2013). Previously, heap leaching was a widely used form of processing ion-adsorption clays, which involves excavating minerals, placing them in a mound, and spraying them with solutions (Papangelaks and Moldoveanu, 2014). Tank/pool leaching involves placing the minerals into a tank/pool and soaked with solutions (Zhao et al., 2001). In-situ leach mining is now the dominating technology, given that there is less topsoil removed (i.e. about one fifth to one third as in the case of heap and tank/pool leaching), the process can be performed on site, and the environmental impacts are reduced ( $\mathrm{Du}, 2001$; $\mathrm{Wu}, 2005$; Schuler et al., 2011). For these reasons this study focuses on in situ leaching only.

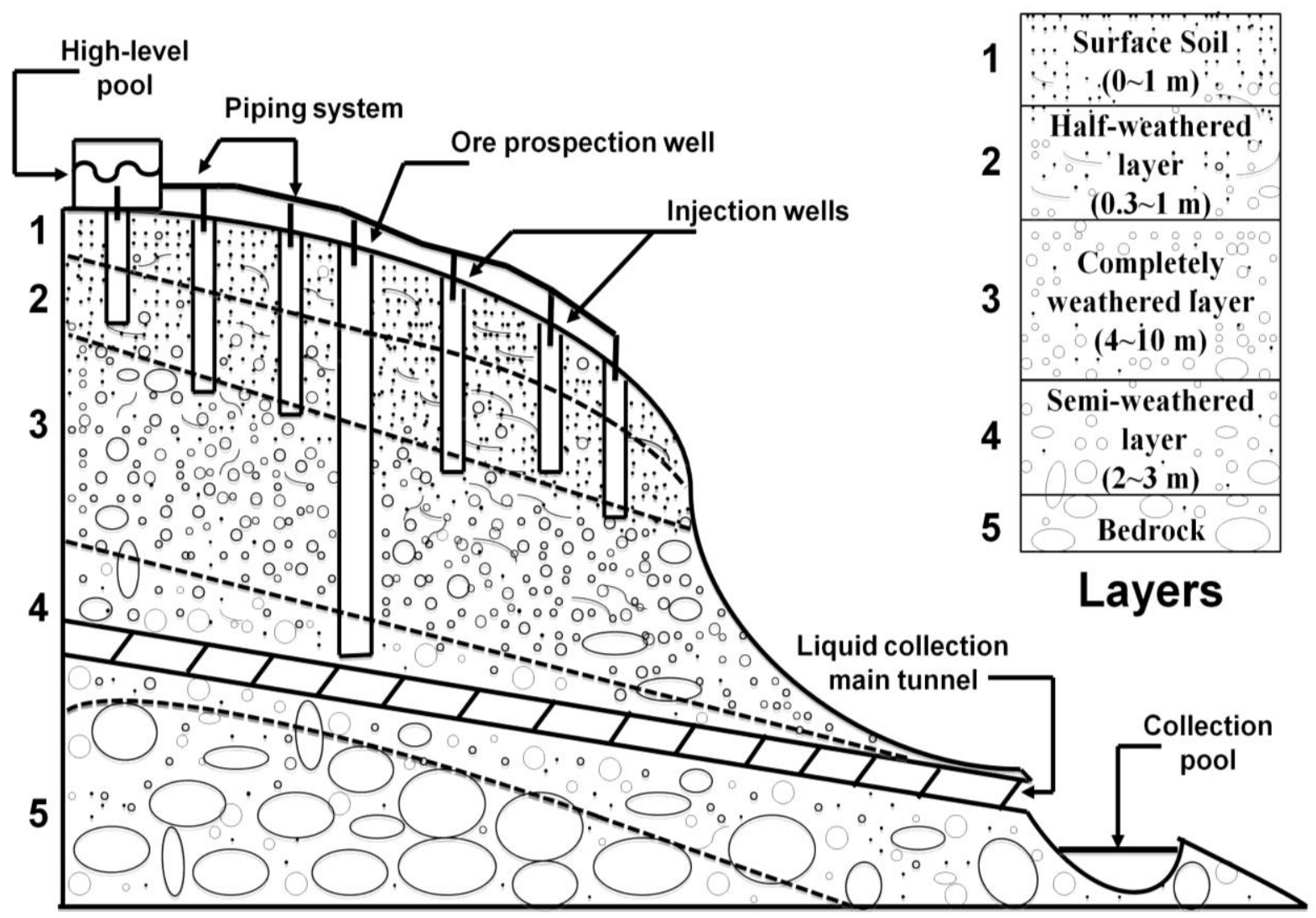


Figure 1. Typical layers of mining site for ion adsorption clays (adapted from Zou, 2012)

Before in-situ leaching is carried out, a proper mining site has to be selected (i.e. mining exploration). Factors considered include geological structures, hydrogeological features, ore deposit features, production condition, bedrock composition, permeability of bedrocks, and hydrogeology of the mining zone (Papangelakis and Moldeveanu, 2014; Zhao, 2001). According to Tang and $\mathrm{Li}$ (1997), the area where ore is accessible for in situ leaching is typically between 5,000-10,000 $\mathrm{m}^{2}$, with the thickness of the ore body being between 5-20 $\mathrm{m}$ (Xiao et al., 2003a; Zou, 2012). After the mining site is selected, topsoil is removed and holes (to serve as injection wells) are drilled.

A common practice is to have injections wells of $0.6-0.8 \mathrm{~m}$ diameter at a depth between 2-6 m placed throughout the site with interval 5m by $5 \mathrm{~m}$ (Xiao et al., 2003a; Yang et al., 2013; Zhao, 2001). PVC piping is used to build a pipeline network (Luo et al., 2014), which consists of two pipe systems: one with ammonium sulfate $\left(\left(\mathrm{NH}_{4}\right)_{2} \mathrm{SO}_{4}\right)$ for the ion exchange mechanism and for fresh water flushing at the end of mining (Zhu et al., 2013), and the other being a leachate collection pipeline system where pools are built close the hillside and organized in terraces (MEP, 2011; Walters et al., 2011).

The reaction equation of the in-situ leaching of ion-adsorption clays with ammonium sulfate (1-2\% w/w concentration) is described by Equation 1. Leaching can also be carried out using other concentrated inorganic salt solutions such as of $\mathrm{Na}_{2} \mathrm{SO}_{4}, \mathrm{NH}_{4} \mathrm{Cl}$, and $\mathrm{NaCl}$ (Jun et al., 2010; Navarro and Zhao, 2014). When leaching is finished (i.e., after 150-400 days), fresh water is injected to drive out the remaining REE-bearing solutions (Yang et al., 2013). The rare earth concentration in the leachate is low, and every liter of solution usually contains only several grams of REOs.

$$
2(\text { Clay })^{3-} \mathrm{REE}^{3+}+3\left(\mathrm{NH}_{4}\right)_{2}{ }^{1+} \mathrm{SO}_{4}{ }^{2-} \rightarrow 2(\text { Clay })^{3-}\left(\mathrm{NH}_{4}\right)_{3}{ }^{1+}+\mathrm{REE}_{2}{ }^{3+}\left(\mathrm{SO}_{4}\right)_{3}{ }^{2-}
$$

To recover REEs from the leachate, precipitation is carried out (Luo et al., 2014; Jun et al, 2011). Ammonium bicarbonate $\left(\mathrm{NH}_{4} \mathrm{HCO}_{3}\right)$ or oxalic acid $\left(\mathrm{H}_{2} \mathrm{C}_{2} \mathrm{O}_{4}\right)$ are the two chemicals commonly 
used (Kynicky et al., 2012; Walters et al., 2011; Yu et al., 1990). The reactions with ammonium bicarbonate and oxalic acid are giving by Equations 2 and 3, respectively (Luo et al., 2014; Zhao et al, 2001). For industrial operations, ammonium bicarbonate is typically used in place of oxalic acid, because of its lower cost and lower environmental impact (Chi et al., 2013). However, it should be noted that precipitation with oxalic acid leads to higher product purity. In addition, using ammonium bicarbonate may cause additional difficulties in the following dehydration process (Luo et al., 2014). The precipitate is pressed to remove water and then calcined at 750$850{ }^{\circ} \mathrm{C}$ to get REOs.

$$
\begin{gathered}
2 \mathrm{RE}^{3+}+3 \mathrm{NH}_{4} \mathrm{HCO}_{3}{ }^{-} \rightarrow \mathrm{RE}_{2}\left(\mathrm{CO}_{3}\right)_{3}+3 \mathrm{NH}_{4}{ }^{+}+3 \mathrm{H}^{+} \\
2 \mathrm{RE}^{3+}+3 \mathrm{H}_{2} \mathrm{C}_{2} \mathrm{O}_{4}+\mathrm{xH}_{2} \mathrm{O} \rightarrow \mathrm{RE}_{2}\left(\mathrm{C}_{2} \mathrm{O}_{4}\right)_{3} \cdot \mathrm{xH}_{2} \mathrm{O}+6 \mathrm{H}^{+}
\end{gathered}
$$




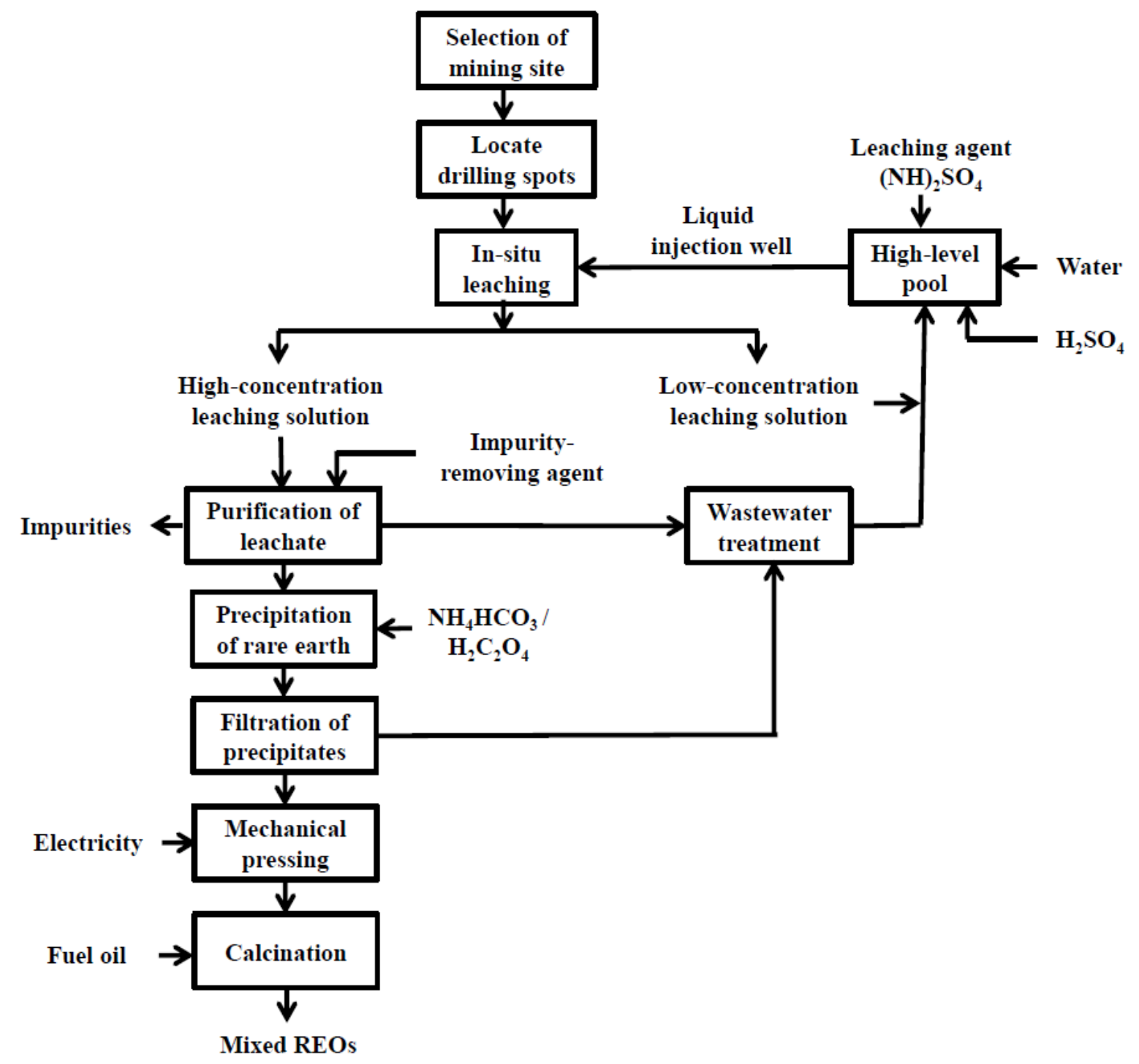

Figure 2. Flow diagram of ion-adsorption process used in southern China (Luo et al., 2014).

Figure 2 shows a typical process flow diagram of in-situ leaching performed in southern China. Unlike processing bastnasite and monazite, in situ leaching of ion adsorption clay does not involve a beneficiation process, and REEs are extracted solely via hydrometallurgical processes (Golev, 2014; Jordens et al., 2013). In-situ leaching process usually can achieve extraction efficiencies greater than $90 \%$ (Xiao et al., 2003b), with final products of purity 90-92\% (Schuler et al., 2011). If further processing is desired on site, a rough solvent extraction can be performed (Zhao, 2001). 
In additional to the chemicals mentioned above, $\mathrm{H}_{2} \mathrm{SO}_{4}$ is used to adjust the $\mathrm{pH}$ levels of the solution. Electricity demand for the mining equipment (air compressors, water pump, etc.) also adds to the process inputs. For a typical in situ leaching site, power demand is in the $100 \mathrm{~kW}$ range $(\mathrm{Li}, 2011)$. Electricity usage and cost depends on the site, technology, and local source availability (China Aluminum Corporation, 2014).

Residue out of the process contains $U$ and Th, but the concentrations are much lower than the processing of open-pit mining of bastnasite and monazite, and in general will not lead to significant environmental impacts (Lianfeng, 1999). However, it has been reported that there are increased concentrations of $\left(\mathrm{NH}_{4}\right)_{2} \mathrm{SO}_{4}$ in groundwater and increased concentrations of $\mathrm{NH}_{4}{ }^{+}$and REEs in the surface water (Zhu et al., 2011).

\section{Methodology}

Standard LCA methodology was implemented for the study. The four steps according to ISO standards are: goal and scope definition, life cycle inventory analysis, life cycle impact assessment, and interpretation (ISO, 2006).

\subsection{Goal and scope}

\subsubsection{Investigated regions}

In site leaching of ion adsorption clays is mainly performed in the southern provinces of China i.e. Fujian, Guangdong, Guangxi, Hunan, Jiangxi, Yunnan, and Zhejiang (Lu et al., 2014; Schuler et al., 2011; Wu, 2005). The regional climate is warm and humid, with annual rainfalls over $1.50 \mathrm{~m}$ (Bao and Zhao, 2008). It should be noted that in-situ leaching may be performed in other regions of the country, but majority of mining activities occur in aforementioned seven provinces and almost all literature on in-situ leaching of ion adsorption have focused on mining in this region.

\subsubsection{System boundary and assumption}

Figure 3 presents the system boundary for the LCA study. Selection of mining site (mining exploration) is not included in the system boundary which is in agreement with other LCA studies on REE production (and in general LCA studies on metal production) (Koltun and 
Tharumarajah, 2014; Zaimes et al., 2015). The process ends at mixed rare earth oxides and downstream processes such as solvent extraction and metal production are not included in the system boundary. At certain sites further processing may occur (e.g., separating REEs into light and groups). However, this is not very common and the separation processes adopted varies significantly from site to site. It should be noted that further treatment of REOs i.e. separating individual REE via hundreds steps of solvent extraction and production of rare earth metals via reduction are performed at off-site, centralized facilities due to high capital investment. These facilities usually accept mixed REOs from different mining sites, including REOs from bastnasite and monazite (Eggert et al., 2008; Kynicky et al., 2012).

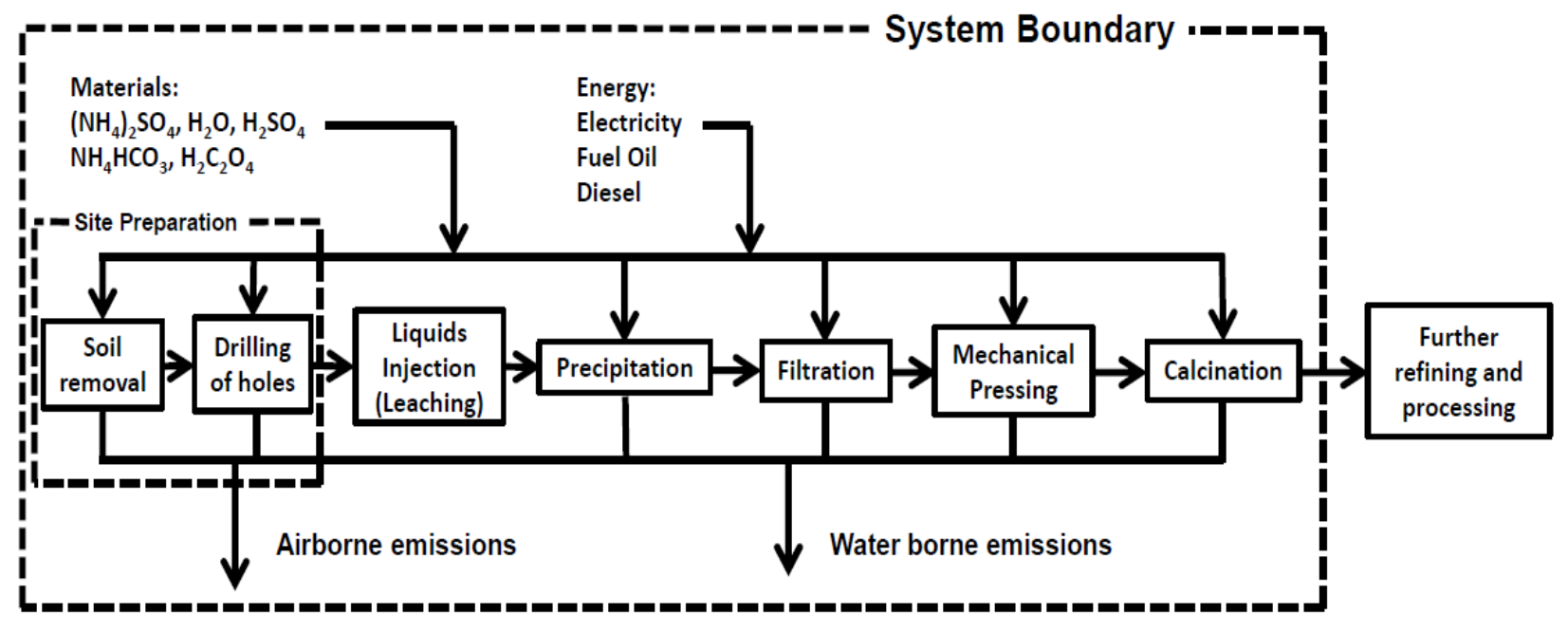

Figure 3. System boundary for this LCA study.

\subsubsection{Functional unit}

For bastnasite and monazite, the major steps involved in the production of REEs include mining, physical beneficiation, chemical beneficiation, solvent extraction, and metal refining. For the route of ion adsorption clays, the first three steps are replaced by the in situ leaching process described in Section 2, but the remaining steps are the same. The intermediate products coming out of chemical beneficiation are mixed REE compounds (usually in the form of REE oxides, carbonates, or chlorides). It is a common practice to present the throughput of a facility in term of REE oxides (REOs) equivalent. To determine the environmental impact of the process, it is 
necessary to clearly define a functional unit. To facilitate comparison, in this paper the functional unit is defined as the production of $1 \mathrm{~kg}$ of 90-92\% purity mixed REOs by the in-situ leaching method from ion-adsorption clays in southern China.

\subsection{Life cycle inventory analysis}

In this study, the material and energy flow data is gathered from Chinese literature and verified through personal communications with Chinese experts working in this industry (Xiao et al, 2003a; Zhang et al., 2009; Li, 2011; Zou, 2012 ). Inventory analysis is carried out using SimaPro 8 and Ecoinvent 3.0. In addition to data from literature, the emission limits set in the "Emission Standards of Pollutants from Rare Earths Industry" are used as the best case scenario (China Ministry of Environmental Protection, 2011).

Table 2 shows the major material and energy inputs and emissions for the in situ leaching process. It should be noted that the datasets from the "Allocation, default system model" in Ecoinvent 3 (Alloc. Def.) are used. These datasets are derived based on attributional modeling (instead of consequential) and for most multi-products processes economic allocation is used. Since the data was collected from different sources (Xiao et al, 2003b; Zhang et al., 2009; Li, 2011; Zou, 2012; Nuss \& Eckelman, 2014; Sprecher et al., 2014; Zaimes et al., 2015) and there exist variations from site to site, the ranges are presented. It is possible that in situ leaching process might mobilize some heavy metals; however, there have been contradicting reports on heavy metal releases from mining ion adsorption clays. In one study, monitoring data does not seem to suggest noticeable increase of heavy metals in soil and water bodies close to a mining site in Longnan City, Jiangxi Province (Du, 2001).

In another study, Su (2009) estimated that almost 1000 tons wastewater containing heavy metals is generated to produce 1 ton rare earth oxide from ion-adsorption rare earth ores during in situ and heap leaching processes. In addition, elevated level of $\mathrm{Mn}, \mathrm{Pb}$, and $\mathrm{Zn}$ were found in the soil and vegetation close to a tailing site in Hexuan City, Guangdong Province (Liu et al., 2014). In this study, only ammonium (in the form of ammonium sulfate) was considered for the waterborne emission and possible release of heavy metals is left for future LCA studies. 
The water borne emission of ammonium mainly comes from two sources. According to Equation (1), during ion exchange 3 moles of ammonium is needed per mole of REE extracted. In addition to REEs, other metal ions will also be mobilized into leachate. Using the average molecular weight of REEs (i.e. 132), it can be calculated that per $\mathrm{kg}$ REO produced $0.36 \mathrm{~kg}$ ammonium is left in the soil. In addition, leaking is inevitable during in situ leaching and the amount is usually $8-10 \%$ of the total leaching solution consumed. It should be noted that ammonium emission due to ion exchange and leaking is impossible to reduce.

The other major source of ammonium release is the effluent from processing the collected leachate. The worst-case scenario would be no wastewater treatment is done and all ammonium is released into environment. The best-case scenario would be all wastewater is treated on site and the effluent discharged meets the emission standard of China Ministry of Environmental Protection (i.e. $50 \mathrm{mg} / \mathrm{L})$.

For electricity usage, cost is usually presented in literature and a wide range has been reported i.e. 0.25-2.5 Chinese Yuan/kg REO (Zou, 2012; Li, 2011). The wide range is likely due to the availability of fresh water and the elevation of the mining zone thus the energy needed to pump water. The electricity consumption is calculated assuming an average electricity cost of 0.43 Chinese Yuan/kWhr. It should be noted that this price is for agriculture users. Since most in situ leaching facilities draw electricity from villages nearby, this assumption is reasonable. For water usage, it is assumed that the water used comes from water bodies close to the mining site and only minimal treatment (sedimentation and sand filtration) is performed. As a result, electricity is the only major input and is accounted in the total electricity consumption.

Table 2. Life cycle inventory data for production of $1 \mathrm{~kg}$ REO from ion-adsorption clays

\begin{tabular}{lcccl}
\hline Input & Low & High & Unit & Ecoinvent Unit Process \\
\hline $\begin{array}{l}\text { Site preparation } \\
\text { Soil removal and hole drilling }\end{array}$ & 1.1 & 1.2 & $\mathrm{~m}^{3}$ & $\begin{array}{l}\text { Excavation, hydraulic digger }\{\text { China }\} \mid \text { processing } \mid \\
\text { Alloc Def, } \mathrm{U}\end{array}$ \\
$\begin{array}{l}\text { PVC pipes } \\
\text { (Materials/Processes) }\end{array}$ & 0.092 & 0.100 & $\mathrm{~kg}$ & $\begin{array}{l}\text { Polyvinylchloride, suspension polymerised } \\
\text { \{China }\} \mid \text { polyvinylchloride production, } \\
\text { suspension polymerisation } \mid \text { Alloc Def, U }\end{array}$
\end{tabular}




$\begin{array}{llll}0.004 & 0.006 & \mathrm{~kg} & \begin{array}{l}\text { Limestone, crushed, for mill }\{\text { China }\} \mid \text { production } \\ \text { Alloc Def, } \mathrm{U}\end{array} \\ 0.096 & 0.106 \quad \mathrm{~kg} & \begin{array}{l}\text { Extrusion, plastic pipes }\{\text { China }\} \mid \text { production } \\ \text { Alloc Def, } \mathrm{U}\end{array}\end{array}$

Extraction step

\begin{tabular}{|c|c|c|c|c|}
\hline Ammonium sulfate & 6.1 & 10.4 & $\mathrm{~kg}$ & $\begin{array}{l}\text { Ammonium sulfate, as } \mathrm{N}\{\text { China }\} \mid \text { ammonium } \\
\text { sulfate production } \mid \text { Alloc Def, } \mathrm{U}\end{array}$ \\
\hline Ammonium bicarbonate & 2.2 & 4.5 & $\mathrm{~kg}$ & $\begin{array}{l}\text { Ammonium bicarbonate }\{\text { China }\} \mid \text { production | } \\
\text { Alloc Def, } U\end{array}$ \\
\hline Sulfuric acid & 0.3 & 0.75 & $\mathrm{~kg}$ & Sulfuric acid $\{$ China $\} \mid$ production $\mid$ Alloc Def, $U$ \\
\hline Water & \multicolumn{2}{|c|}{1000} & liter & $\begin{array}{l}\text { Water, deionized, from tap water, at user }\{\text { GLO }\} \mid \\
\text { market for } \mid \text { Alloc Def, } U\end{array}$ \\
\hline Oxalic acid & 1.2 & 1.5 & $\mathrm{~kg}$ & Citric acid $\{\mathrm{CN}\} \mid$ production $\mid$ Alloc Def, $\mathrm{U}$ \\
\hline Electricity & 0.53 & 5.3 & $\mathrm{kWhr}$ & $\begin{array}{l}\text { Electricity, medium voltage }\{\mathrm{CN}\} \mid \text { market for } \mid \\
\text { Alloc Def, } U\end{array}$ \\
\hline Calcination & 0.624 & 0.780 & MJ & $\begin{array}{l}\text { Heat, district or industrial, other than natural gas } \\
\{\mathrm{CN}\} \mid \text { treatment of blast furnace gas, in power } \\
\text { plant } \mid \text { Alloc Def, } U\end{array}$ \\
\hline \multicolumn{5}{|l|}{ Direct Emission } \\
\hline $\mathrm{NH}_{4}^{+}$as emission to water & 0.26 & 3.5 & $\mathrm{~kg}$ & Ammonium, ion \\
\hline $\mathrm{SO}_{4}^{2-}$ as emission to water & 4.72 & 8.28 & $\mathrm{~kg}$ & Sulfate \\
\hline $\mathrm{CO}_{2}$ release (from calcination) & \multicolumn{2}{|c|}{0.46} & $\mathrm{~kg}$ & Carbon dioxide \\
\hline $\mathrm{NH}_{4}^{+}$as emission to soil & \multicolumn{2}{|c|}{0.34} & $\mathrm{~kg}$ & Ammonium, ion \\
\hline
\end{tabular}

Given the limit coverage of the Ecoinvent database, European averages (RER) or global averages (GLO) were used with energy mix (electricity, heat and diesel) adjusted to reflect production in China $(\mathrm{CN})$. In addition, citric acid $(\mathrm{CN})$ was used in place of oxalic acid, since an Ecoinvent unit process for oxalic acid does not exist. It may be noted that Nuss and Eckelman (2014) performed an LCA of metals and utilized the same substitution. Since oxalic acid and citric acid can both be industrially produced from carbon monoxide, this substitution was found to be acceptable (Riemenschneider and Tanifuji, 2011). The contribution for capital equipment (e.g. hydraulic digger and water pumps) is very small (less than $1 \%$ based on Ecoinvent datasets) thus excluded. 


\subsection{Impact Assessment}

In this study, TRACI (Tool for the Reduction and Assessment of Chemical and Other Environmental Impacts) developed by United States Environmental Protection Agency (US EPA) was used to assess environmental assessment. To facilitate the use of results in EU, ILCD (International Reference Life Cycle Data) method developed by the Institute for Environment and Sustainability in the European Commission Joint Research Centre (JRC) was also used. Both methods are widely used in LCA studies. For TRACI, impact categories included are Ozone depletion (kg CFC-11 eq), Global warming(kg CO2 eq), Smog (kg O3 eq), Acidification (kg SO2 eq), Eutrophication (kg N eq), Carcinogenics (CTUh), Non carcinogenics (CTUh), Respiratory effects (kg PM2.5 eq), Ecotoxicity (CTUe), and Fossil fuel depletion (MJ surplus). For ILCD, impact categories include: Climate change (kg CO2 eq), Ozone depletion (kg CFC-11 eq), Human toxicity, non-cancer effects (CTUh), Human toxicity, cancer effects (CTUh), Particulate matter (kg PM2.5 eq), Ionizing radiation $\mathrm{HH} \quad(\mathrm{kBq} \mathrm{U} 235 \mathrm{eq})$, Ionizing radiation E (interim) (CTUe), Photochemical ozone formation (kg NMVOC eq), Acidification (molc H+ eq), Terrestrial eutrophication (molc $\mathrm{N}$ eq), Freshwater eutrophication (kg $\mathrm{P}$ eq), Marine eutrophication (kg N eq), Freshwater ecotoxicity (CTUe), Land use (kg C deficit), Water resource depletion (m3 water eq), Mineral, fossil \& renewable resource depletion ( $\mathrm{kg} \mathrm{Sb} \mathrm{eq).}$ Cumulative energy demand (CED) was also calculated as it is commonly found in published LCA studies on REEs.

\section{Results and Discussion}

\subsection{Environmental Impacts of in situ Leaching}

Table 3 shows the results of the LCIA using TRACI and CED, with a low estimation and a high estimation for all the ten impact categories considered. It can be seen that due to varying site and process conditions, there could be significant difference with regard to environmental impacts.

Table 3. Low and high estimates of life cycle impacts for ion adsorption clays using TRACI.

\begin{tabular}{lcccc|cc}
\hline Impact category & Unit & Low & High & $\begin{array}{c}\text { Aluminum } \\
\text { Oxide }\end{array}$ & $\begin{array}{c}\text { REO Low } \\
/ \mathbf{A l}_{\mathbf{2}} \mathbf{O}_{\mathbf{3}}\end{array}$ & $\begin{array}{c}\text { REO High } \\
/ \mathbf{A l}_{\mathbf{2}} \mathbf{O}_{\mathbf{3}}\end{array}$ \\
\hline Global warming & $\mathrm{kg} \mathrm{CO} 2-\mathrm{Eq}$ & $2.09 \mathrm{E}+01$ & $3.55 \mathrm{E}+01$ & $1.74 \mathrm{E}+00$ & $1.20 \mathrm{E}+01$ & $2.04 \mathrm{E}+01$ \\
Acidification & $\mathrm{kg} \mathrm{SO} 2 \mathrm{eq}$ & $1.65 \mathrm{E}-01$ & $2.88 \mathrm{E}-01$ & $1.63 \mathrm{E}-02$ & $1.01 \mathrm{E}+01$ & $1.77 \mathrm{E}+01$ \\
Carcinogenics & $\mathrm{CTUh}$ & $1.39 \mathrm{E}-06$ & $2.21 \mathrm{E}-06$ & $2.03 \mathrm{E}-06$ & $6.85 \mathrm{E}-01$ & $1.09 \mathrm{E}+00$
\end{tabular}




\begin{tabular}{lcccc|cc} 
Non-carcinogenics & CTUh & $1.04 \mathrm{E}-05$ & $1.69 \mathrm{E}-05$ & $1.27 \mathrm{E}-06$ & $8.19 \mathrm{E}+00$ & $1.33 \mathrm{E}+01$ \\
Respiratory effects & kg PM2.5 eq & $2.59 \mathrm{E}-02$ & $4.47 \mathrm{E}-02$ & $1.40 \mathrm{E}-03$ & $1.85 \mathrm{E}+01$ & $3.19 \mathrm{E}+01$ \\
Eutrophication & kg N eq & $3.03 \mathrm{E}-01$ & $2.87 \mathrm{E}+00$ & $5.67 \mathrm{E}-03$ & $5.34 \mathrm{E}+01$ & $5.06 \mathrm{E}+02$ \\
Ozone depletion & kg CFC-11 eq & $2.43 \mathrm{E}-06$ & $3.21 \mathrm{E}-06$ & $1.74 \mathrm{E}-07$ & $1.40 \mathrm{E}+01$ & $1.84 \mathrm{E}+01$ \\
Ecotoxicity & CTUe & $2.79 \mathrm{E}+02$ & $4.49 \mathrm{E}+02$ & $7.23 \mathrm{E}+01$ & $3.86 \mathrm{E}+00$ & $6.21 \mathrm{E}+00$ \\
Smog & kg O3 eq & $1.56 \mathrm{E}+00$ & $2.62 \mathrm{E}+00$ & $1.72 \mathrm{E}-01$ & $9.07 \mathrm{E}+00$ & $1.52 \mathrm{E}+01$ \\
Resource, Fossil Fuel & MJ surplus & $1.26 \mathrm{E}+01$ & $1.77 \mathrm{E}+01$ & $2.71 \mathrm{E}+00$ & $4.65 \mathrm{E}+00$ & $6.53 \mathrm{E}+00$ \\
$\begin{array}{l}\text { Depletion } \\
\text { CED }\end{array}$ & & & & & & \\
\hline
\end{tabular}

For categories other than eutrophication in which the high estimate is almost nine times of the low estimate, the high estimate is about $130 \%$ to $180 \%$ of the low estimate. For eutrophication, the difference is much higher (i.e. 900\%). The reason is that the low estimate represents an ideal case which assumes the facility has wastewater treatment unit and the effluent meets emission standard i.e. $50 \mathrm{mg} / \mathrm{L}$ ammonium. In this best case scenario, ammonium release is largely due to ion exchange and leakage. In reality, however, due to lack of enforcement, many mining facilities do not treat wastewater thus all ammonium is released into environment. Studies report that the actual effluent could contain ammonium up to $4000 \mathrm{mg} / \mathrm{L}$, which is in agreement with the high estimate on ammonium release listed in Table 2.

Table 3 also shows environmental impacts of REOs normalized to aluminum oxide. Here aluminum oxide is selected as the basis because it is the intermediate in the primary aluminum production pathway. This is similar to the case of REE production. In addition, reliable data is available for aluminum oxide production. Data suggests that in general production of REOs from ion adsorption clays carries much higher impacts in almost all categories. The only exception is carcinogenics, for which the impacts are similar between the two.

Table 4 shows the results using ILCD for fourteen impact categories. Similar to the results for TRACI, the variation between high and low estimations is almost $130 \%$ to $190 \%$ for all environmental categories except marine eutrophication in which higher estimation is $1100 \%$ larger than lower estimation. To identify flows that contribute most to these environmental impacts, Table 5 gives the contributions (in percentage) of each entry listed in Table 2 using data reported for a mining site in Jiangxi province (Zou et al. 2012). As expected direct water borne emission dominates the eutrophication due to the large amount of ammonium discharged to soil 
and water during ion exchange and wastewater disposal. Similar to Table 3, aluminum oxide was chosen and the environmental impacts of REO production were compared with aluminum oxide production in Table 4. Again, REO production has much higher impacts than aluminum oxide in almost all categories, with the only exception being human toxicity (cancer related).

Table 4. Low and high estimates of life cycle impacts for ion adsorption clays using ILCD.

\begin{tabular}{|c|c|c|c|c|c|c|}
\hline Impact category & Unit & Low & High & $\begin{array}{c}\text { Aluminum } \\
\text { Oxide }\end{array}$ & $\begin{array}{c}\text { REO Low } \\
/ \mathrm{Al}_{\mathbf{2}} \mathrm{O}_{\mathbf{3}}\end{array}$ & $\begin{array}{c}\text { REO High } \\
/ \mathrm{Al}_{2} \mathrm{O}_{3} \\
\end{array}$ \\
\hline Climate change & $\mathrm{kg} \mathrm{CO} 2 \mathrm{eq}$ & $2.09 \mathrm{E}+01$ & $3.55 \mathrm{E}+01$ & $1.74 \mathrm{E}+00$ & $1.20 \mathrm{E}+01$ & $2.04 \mathrm{E}+01$ \\
\hline Ozone depletion & $\mathrm{kg} \mathrm{CFC-11} \mathrm{eq}$ & $2.33 \mathrm{E}-06$ & $3.07 \mathrm{E}-06$ & $1.51 \mathrm{E}-07$ & $1.55 \mathrm{E}+01$ & $2.04 \mathrm{E}+01$ \\
\hline $\begin{array}{l}\text { human toxicity } \\
\text { (non-cancer related) }\end{array}$ & CTUh & $1.04 \mathrm{E}-05$ & $1.69 \mathrm{E}-05$ & $1.27 \mathrm{E}-06$ & $8.19 \mathrm{E}+00$ & $1.33 \mathrm{E}+01$ \\
\hline $\begin{array}{l}\text { human toxicity } \\
\text { (cancer related) }\end{array}$ & CTUh & $1.39 \mathrm{E}-06$ & $2.21 \mathrm{E}-06$ & $1.03 \mathrm{E}-06$ & $1.34 \mathrm{E}+00$ & $2.14 \mathrm{E}+00$ \\
\hline Particulate matters & $\mathrm{kg}$ PM2.5 eq & $3.17 \mathrm{E}-02$ & $6.01 \mathrm{E}-02$ & $1.55 \mathrm{E}-03$ & $2.04 \mathrm{E}+01$ & $3.87 \mathrm{E}+01$ \\
\hline Ionizing radiation & $\mathrm{kBq} \mathrm{U} 235 \mathrm{eq}$ & $1.62 \mathrm{E}+00$ & $2.27 \mathrm{E}+00$ & $1.23 \mathrm{E}-01$ & $1.32 \mathrm{E}+01$ & $1.85 \mathrm{E}+01$ \\
\hline $\begin{array}{l}\text { Photochemical ozone } \\
\text { formation }\end{array}$ & kg NMVOC eq & $9.81 \mathrm{E}-02$ & $1.65 \mathrm{E}-01$ & 8.97E-03 & $1.09 \mathrm{E}+01$ & $1.84 \mathrm{E}+01$ \\
\hline Acidification & molc $\mathrm{H}+\mathrm{eq}$ & $1.99 \mathrm{E}-01$ & $3.49 \mathrm{E}-01$ & $1.98 \mathrm{E}-02$ & $1.00 \mathrm{E}+01$ & $1.76 \mathrm{E}+01$ \\
\hline Terrestrial eutrophication & molc $\mathrm{N}$ eq & $2.86 \mathrm{E}-01$ & 4.64E-01 & $3.06 \mathrm{E}-02$ & $9.35 \mathrm{E}+00$ & $1.52 \mathrm{E}+01$ \\
\hline Freshwater eutrophication & $\mathrm{kg} \mathrm{P}$ eq & $1.11 \mathrm{E}-02$ & $1.78 \mathrm{E}-02$ & $6.02 \mathrm{E}-04$ & $1.84 \mathrm{E}+01$ & $2.96 \mathrm{E}+01$ \\
\hline Marine eutrophication & $\mathrm{kg} \mathrm{N}$ eq & $2.40 \mathrm{E}-01$ & $2.77 \mathrm{E}+00$ & $2.77 \mathrm{E}-03$ & $8.66 \mathrm{E}+01$ & $1.00 \mathrm{E}+03$ \\
\hline Ecotoxicity & CTUe & $2.80 \mathrm{E}+02$ & $4.51 \mathrm{E}+02$ & $7.23 \mathrm{E}+01$ & $3.87 \mathrm{E}+00$ & $6.23 \mathrm{E}+00$ \\
\hline Water resource & m3 water eq & $2.99 \mathrm{E}+01$ & $5.36 \mathrm{E}+01$ & $7.36 \mathrm{E}-01$ & $4.06 \mathrm{E}+01$ & $7.28 \mathrm{E}+01$ \\
\hline $\begin{array}{l}\text { Resource depletion, } \\
\text { mineral, fossils, and } \\
\text { renewables }\end{array}$ & $\mathrm{kg} \mathrm{Sb}$ eq & $2.98 \mathrm{E}-03$ & $4.67 \mathrm{E}-03$ & $4.01 \mathrm{E}-05$ & $7.44 \mathrm{E}+01$ & $1.17 \mathrm{E}+02$ \\
\hline
\end{tabular}

It should be noted that the inventory shown in Table 2 does not include the consumption of rare earth ores i.e. ion adsorption clays. This means that the resource depletion results shown in Tables 3 and 4 are underestimates. The characterization model/factors used in TRACI does not cover REEs. While ILCD does have characterization factors for rare earth elements as part of mineral depletion, the model employed is based on CML method. As pointed out by Adibi et al. (2014), although CML method for resource depletion has been recommended by EU commission 
(and adopted in ILCD), the method does not quantify resource depletion well in the case of rare earths. CML method on resource depletion is based on annual production and abundance. Unfortunately rare earth is not really "rare" and the difficulty lies on the fact that no many concentrated rare earth ores are available.

Among all the chemicals consumed, ammonium sulfate is one of the largest contributors to most of the impact categories. In practice, sodium chloride has been used as an alternative. However, sodium ion can only offer a much lower selectivity than ammonium. As a result, when sodium chloride is used the concentration is usually $7-8 \%$, which is much higher than the case of ammonium sulfate (1-2\%). Discharging large amount of sodium will harm soil fertility. In addition, products coming out of precipitation tend to have lower purity (Shi, 2009). It should also be noted that contributions from oxalic acid are quite significant in most categories. Since citric acid is used as a surrogate for oxalic acid, developing an LCI for oxalic acid is highly desirable in order to reduce model uncertainties.

Table 5. Contributions of material/energy flows and process emission.

\begin{tabular}{|c|c|c|c|c|c|c|}
\hline Impact category & $\begin{array}{c}\text { Direct } \\
\text { emission }\end{array}$ & $\begin{array}{l}\text { Ammonium } \\
\text { sulphate }\end{array}$ & $\begin{array}{l}\text { Ammonium } \\
\text { bicarbonate }\end{array}$ & $\begin{array}{l}\text { Oxalic } \\
\text { acid }\end{array}$ & Electricity & $\begin{array}{l}\text { Site Prep. \& } \\
\text { Water }\end{array}$ \\
\hline Global Warming & $0 \%$ & $22 \%$ & $17 \%$ & $34 \%$ & $17 \%$ & $10 \%$ \\
\hline Acidification & $0 \%$ & $22 \%$ & $15 \%$ & $36 \%$ & $20 \%$ & $7 \%$ \\
\hline Carcinogenics & $0 \%$ & $55 \%$ & $10 \%$ & $23 \%$ & $4 \%$ & $8 \%$ \\
\hline Non-carcinogenics & $0 \%$ & $62 \%$ & $11 \%$ & $20 \%$ & $3 \%$ & $4 \%$ \\
\hline Respiratory effects & $0 \%$ & $40 \%$ & $15 \%$ & $25 \%$ & $14 \%$ & $6 \%$ \\
\hline Eutrophication & $95 \%$ & $3 \%$ & $1 \%$ & $1 \%$ & $0 \%$ & $0 \%$ \\
\hline Ozone depletion & $0 \%$ & $26 \%$ & $4 \%$ & $54 \%$ & $1 \%$ & $15 \%$ \\
\hline Ecotoxicity & $0 \%$ & $63 \%$ & $11 \%$ & $20 \%$ & $2 \%$ & $4 \%$ \\
\hline Smog & $0 \%$ & $19 \%$ & $17 \%$ & $35 \%$ & $18 \%$ & $11 \%$ \\
\hline $\begin{array}{l}\text { Resouce/Fossil } \\
\text { Fuel }\end{array}$ & $0 \%$ & $26 \%$ & $8 \%$ & $44 \%$ & $5 \%$ & $17 \%$ \\
\hline
\end{tabular}




\subsection{Comparison with Bastnasite/Monazite Route}

It is interesting to compare the environmental profiles of REOs produced from ion adsorption clays via in-situ leaching and those from bastnasite and monazite. Table 6 summaries the published LCA studies on the bastnasite/monazite route as against this study. It can be seen that these studies vary with respect to system boundary, functional unit, and LCIA methods. Since the paper by Nuss and Eckelman has a focus on pure REEs (as metal), and covers a much broader system boundary, it is excluded from further comparison. Table 7 compares the environmental profiles in term of selected impact categories of REOs produced from the ion adsorption route and bastnasite/monazite route.

Table 6. Summary of selected LCA studies on REEs.

\begin{tabular}{|c|c|c|c|c|c|}
\hline Reference & $\begin{array}{c}\text { Nuss \& } \\
\text { Eckelman }\end{array}$ & Sprecher et al. & $\begin{array}{c}\text { Koltun \& } \\
\text { Tharumarajah }\end{array}$ & Zaimes et al. & Current study \\
\hline Year & 2014 & 2014 & 2014 & 2015 & 2015 \\
\hline $\begin{array}{l}\text { Functional } \\
\text { unit }\end{array}$ & $\begin{array}{l}1 \mathrm{~kg} \text { of element } \\
\text { at factory gate }\end{array}$ & $\begin{array}{c}1 \mathrm{~kg} \text { of } 99 \% \text { pure } \\
\text { REO }\end{array}$ & $\begin{array}{c}1 \mathrm{~kg} \text { of } 98.0 \%-99.9 \% \\
\text { purity mixture of } \\
\text { REO }\end{array}$ & $1 \mathrm{~kg}$ of REO & $\begin{array}{l}1 \mathrm{~kg} \text { of } 90- \\
92 \% \text { purity } \\
\text { REO }\end{array}$ \\
\hline Software & SimaPro 8 & CMLCA 5.2 & SimaPro & Not mention & SimaPro 8 \\
\hline $\begin{array}{l}\text { LCIA } \\
\text { method }\end{array}$ & ReCiPe, USETox & CML 2001 & Eco-indicator 99 & TRACI & TRACI/ILCD \\
\hline Database & Ecoinvent 2.2 & Ecoinvent 2.2 & Ecoinvent 2.2 & Ecoinvent 3 & Ecoinvent 3 \\
\hline Ore/Site & $\begin{array}{c}\text { Bastnasite/ } \\
\text { Mountain Pass } \\
\text { and Bayan Obo }\end{array}$ & $\begin{array}{l}\text { Bastnasite- } \\
\text { Monazite/ } \\
\text { Bayan Obo }\end{array}$ & $\begin{array}{c}\text { Bastnasite-Monazite/ } \\
\text { Bayan Obo }\end{array}$ & $\begin{array}{l}\text { Bastnasite- } \\
\text { Monazite/ } \\
\text { Bayan Obo }\end{array}$ & $\begin{array}{c}\text { Ion-adsorption } \\
\text { clays/ } \\
\text { Southern } \\
\text { China }\end{array}$ \\
\hline
\end{tabular}

For the Sprecher et al. study, LCI was recreated and TRACI was used to calculate a new set of environmental profiles. Given the limited information available, assumptions have to be made along the way so caution has to be taken when interpreting those numbers. As shown in Table 7, REOs produced from ion adsorption clays route has similar impacts with regard to global 
warming and cumulative energy demand compared to other REOs processing routes. The study of Sprecher et al. reports smaller impacts over all categories than the other two studies given the functional unit is $99 \%$ pure REOs (i.e. some further refining/separation is included).

On the other hand, for acidification and eutrophication the differences are significant. Processing of bastnasite-monazite leads to much higher acidification. This is due to the release of sulfur dioxide from the chemical beneficiation process, during which concentrated REE ores are roasted with sulfuric acid at $550-750{ }^{\circ} \mathrm{C}$. Contrary to acidification, in site leaching of ion adsorption clays leads to significantly higher eutrophication, even under the best case scenario.

It should be noted that the functional units defined in all LCA studies listed in Table 7 are roughly the same i.e. $1 \mathrm{~kg}$ REOs mixtures. This appears to be a reasonable approach when the processing of monazite and/or bastnasite is analyzed since the REO content in these two ores are quite similar. However, REO mixtures derived from ion adsorption clays have significantly different composition (i.e. higher HREEs content as shown Table 1). HREEs have their own niche applications (thus delivering different "functions") and usually have higher market price. Therefore, it is interesting to present and compare the environmental impacts associated with individual REO derived from different ores.

Table 7. Environmental profiles of REOs produced from ion adsorption clays and bastnasite/monazite

\begin{tabular}{lccccc}
\hline Category & Unit & Sprecher et al. & $\begin{array}{c}\text { Koltun \& } \\
\text { Tharumarajah }\end{array}$ & Zaimes et al. & Current study \\
\hline $\begin{array}{l}\text { Global } \\
\text { warming }\end{array}$ & $\mathrm{kg} \mathrm{CO} 2 \mathrm{eq}$ & $12-16$ & $32.29-34.49$ & $22.98-35.27$ & $20.9-35.5$ \\
$\begin{array}{l}\text { Acidification } \\
\text { Eutrophication }\end{array}$ & $\mathrm{kg} \mathrm{SO}$ eq & $6.4-8.8$ & N/A & $96.27-99.28$ & $0.165-0.288$ \\
$\begin{array}{l}\text { Respiratory } \\
\text { effects }\end{array}$ & $\mathrm{kg} \mathrm{PM} 2.5 \mathrm{eq}$ & N/A & N/A & $0.16-0.18$ & $0.026-0.045$ \\
$\begin{array}{l}\text { Ozone } \\
\text { depletion }\end{array}$ & $\mathrm{kg} \mathrm{CFC-11} \mathrm{eq}$ & $2.0 \mathrm{E}-06-3.5 \mathrm{E}-06$ & N/A & $3.8 \mathrm{E}-06-2.06 \mathrm{E}-05$ & $2.4 \mathrm{E}-06-3.2 \mathrm{E}-06$ \\
$\begin{array}{l}\text { CED } \\
\text { MJ }\end{array}$ & MJ & $174-232$ & $169.2-179.5$ & $315.0-578.8$ & $255-388$ \\
\hline
\end{tabular}


To determine environmental impacts of individual REO, economic value based allocation is adopted here. Let $P i$ represents the market price of $i$-th REO, and $C_{i j}$ represents the concentration of $i$-th REO in the derived REO mixture from ore type $j$, the allocation coefficient for $i$-th REO from ore type $j$ can be calculated as:

$$
x_{i j}=\left(P_{i} * C_{i j}\right) / \sum_{i}\left(P_{i} * C_{i j}\right)=\left(P_{i} * C_{i j}\right) / V_{j}
$$

Here $V_{j}$ is the market value of REO mixture derived from ore type $j$. If it is assumed that the recovery rate is the same for all REOs, $C_{i j}$ is the same as the REE distributions in the original ore (see Table 1). The allocation coefficients for individual REO from different sites are shown in Table 8. It can be seen that due to the different REE composition profiles, allocation coefficients for a given rare earth oxide could vary significantly from ore to ore. The allocation coefficients for HREEs in ion adsorption clays tend to be much higher than those of bastnasite and monazite, while for LREEs the opposite is observed.

Table 8. Allocation coefficients for individual REO from ion-adsorption clays

\begin{tabular}{|c|c|c|c|c|c|c|c|c|c|}
\hline & & Bayan & Mountain & \multicolumn{6}{|c|}{ Ion Adsorption Clay } \\
\hline & & $\begin{array}{c}\text { Bastnasite } \\
+ \\
\text { Monazite } \\
\end{array}$ & Bastnasite & Site A & Site B & Site C & Site D & Site $\mathbf{E}$ & Site F \\
\hline REO & $\begin{array}{c}\text { Pi } \\
\text { US\$/kg }\end{array}$ & & & & $x_{i j}$ & & & & \\
\hline $\mathrm{La}_{2} \mathrm{O}_{3}$ & 13 & $9.4 \%$ & $16.2 \%$ & $0.2 \%$ & $2.1 \%$ & $0.7 \%$ & $4.7 \%$ & $3.5 \%$ & $1.2 \%$ \\
\hline $\mathrm{CeO}_{3}$ & 12 & $17.3 \%$ & $22.1 \%$ & $1.0 \%$ & $0.1 \%$ & $0.1 \%$ & $1.0 \%$ & $0.4 \%$ & $0.1 \%$ \\
\hline $\operatorname{Pr}_{6} O_{11}$ & 95 & $14.0 \%$ & $15.3 \%$ & $0.7 \%$ & $4.3 \%$ & $1.1 \%$ & $8.5 \%$ & $5.4 \%$ & $3.3 \%$ \\
\hline $\mathrm{Nd}_{\mathbf{2}} \mathrm{O}_{3}$ & 77 & $36.9 \%$ & $34.6 \%$ & $2.7 \%$ & $16.4 \%$ & $3.6 \%$ & $28.1 \%$ & $14.1 \%$ & $7.3 \%$ \\
\hline $\mathrm{Sm}_{2} \mathrm{O}_{3}$ & 23 & $0.8 \%$ & $0.7 \%$ & $0.5 \%$ & $0.8 \%$ & $0.4 \%$ & $1.7 \%$ & $1.0 \%$ & $0.7 \%$ \\
\hline $\mathrm{Eu}_{2} \mathrm{O}_{3}$ & 2150 & $11.2 \%$ & $8.0 \%$ & $4.4 \%$ & $19.4 \%$ & $2.7 \%$ & $13.0 \%$ & $6.3 \%$ & $3.1 \%$ \\
\hline $\mathbf{Y}_{2} \mathbf{O}_{3}$ & 50 & $0.6 \%$ & $0.2 \%$ & $21.3 \%$ & $10.6 \%$ & $15.8 \%$ & $6.1 \%$ & $12.9 \%$ & $14.8 \%$ \\
\hline $\mathbf{G d}_{2} \mathrm{O}_{3}$ & 75 & $1.5 \%$ & $0.6 \%$ & $2.9 \%$ & $2.8 \%$ & $3.2 \%$ & $3.8 \%$ & $3.2 \%$ & $2.7 \%$ \\
\hline $\mathbf{T b}_{2} \mathbf{O}_{3}$ & 1750 & $5.1 \%$ & $1.3 \%$ & $13.0 \%$ & $8.6 \%$ & $15.5 \%$ & $10.6 \%$ & $12.0 \%$ & $14.9 \%$ \\
\hline $\mathrm{Dy}_{2} \mathrm{O}_{3}$ & 975 & $2.8 \%$ & $1.1 \%$ & $49.5 \%$ & $32.7 \%$ & $53.0 \%$ & $21.2 \%$ & $38.2 \%$ & $49.2 \%$ \\
\hline $\mathbf{E}_{\mathrm{r} 2} \mathbf{O}_{3}$ & 77 & $0.2 \%$ & $0.0 \%$ & $2.2 \%$ & $1.4 \%$ & $2.0 \%$ & $0.8 \%$ & $1.7 \%$ & $1.7 \%$ \\
\hline
\end{tabular}




\begin{tabular}{lrrrrrrrr}
$\mathbf{Y b}_{\mathbf{2}} \mathbf{O}_{3} \quad 69$ & $0.2 \%$ & $0.0 \%$ & $1.5 \%$ & $0.8 \%$ & $1.8 \%$ & $0.5 \%$ & $1.4 \%$ & $1.0 \%$ \\
\hline \multirow{3}{*}{ REO mixture } & \multicolumn{7}{c}{$\boldsymbol{V}_{\boldsymbol{j}}(\mathbf{U S} \mathbf{\$} / \mathbf{k g})$} \\
\cline { 2 - 9 } & 34.63 & 26.72 & 147.7 & 122.2 & 158.1 & 82.8 & 102.2 & 140.7 \\
\hline
\end{tabular}

\subsection{Discussion}

In the baseline scenario, it was assumed that the electricity required in the in situ leaching process is generated by mix of fuels in China (Electricity, medium voltage $\{\mathrm{CN}\} \mid$ market for | Alloc Def, U). Some small mining operations may use diesel generators (Diesel, burned in diesel-electric generating set $\{$ China $\} \mid$ processing $\mid$ Alloc Def, $U$ ) to produce electricity. Table 9 illustrates the effects of different electricity generation on environmental impacts (TRACI) of 1 $\mathrm{kg}$ REOs using high estimates. Here the emissions from diesel generator are assumed to meet the Chinese standard on off-road diesel engines (State Environmental Protection Administration; 2007). It can be seen neither power grid or diesel generator has a clear advantage over the other. Since electricity is not a major contributor to any impact category, the effects on the final results are relatively small.

Some of the negative environmental impacts caused by in-situ leaching are difficult to quantify. For example, in-situ leaching may damage vegetation, trigger landslides (given the favorable climate conditions), and cause ground subsidence (Zou et al., 2014). These impacts may happen over long term and may not be seen during mining. This can get even more complicated as each mine site has its unique geological characteristics.

Table 9. TRACI results for per kg REO mixture: electricity generation by mix of fuels vs diesel

\begin{tabular}{lccccc}
\hline Impact category & Unit & $\begin{array}{c}\text { Mix of Fuels } \\
\text { per kWhr }\end{array}$ & $\begin{array}{c}\text { Diesel } \\
\text { per kWhr }\end{array}$ & $\begin{array}{c}\text { Mix of Fuels } \\
\text { per kg REOs }\end{array}$ & $\begin{array}{c}\text { Diesel } \\
\text { per kg REOs }\end{array}$ \\
\hline Ozone depletion & $\mathrm{kg} \mathrm{CFC}-11 \mathrm{eq}$ & $1.41 \mathrm{E}-09$ & $2.73 \mathrm{E}-08$ & $2.69 \mathrm{E}-08$ & $5.21 \mathrm{E}-07$ \\
Global warming & $\mathrm{kg} \mathrm{CO}_{2} \mathrm{eq}$ & $3.16 \mathrm{E}-01$ & $3.40 \mathrm{E}-01$ & $6.03 \mathrm{E}+00$ & $6.48 \mathrm{E}+00$ \\
Smog & $\mathrm{kg} \mathrm{O}_{3} \mathrm{eq}$ & $2.46 \mathrm{E}-02$ & $1.40 \mathrm{E}-01$ & $4.69 \mathrm{E}-01$ & $2.67 \mathrm{E}+00$ \\
Acidification & $\mathrm{kg} \mathrm{SO}_{2} \mathrm{eq}$ & $2.95 \mathrm{E}-03$ & $4.32 \mathrm{E}-03$ & $5.62 \mathrm{E}-02$ & $8.23 \mathrm{E}-02$ \\
Eutrophication & $\mathrm{kg} \mathrm{N} \mathrm{eq}$ & $3.56 \mathrm{E}-04$ & $3.03 \mathrm{E}-04$ & $6.79 \mathrm{E}-03$ & $5.78 \mathrm{E}-03$ \\
Carcinogenics & $\mathrm{CTUh}$ & $4.96 \mathrm{E}-09$ & $1.08 \mathrm{E}-09$ & $9.47 \mathrm{E}-08$ & $2.05 \mathrm{E}-08$ \\
Non carcinogenics & $\mathrm{CTUh}$ & $2.62 \mathrm{E}-08$ & $9.65 \mathrm{E}-09$ & $5.00 \mathrm{E}-07$ & $1.84 \mathrm{E}-07$
\end{tabular}




\begin{tabular}{lccccc} 
Respiratory effects & $\mathrm{kg} \mathrm{PM} 2.5 \mathrm{eq}$ & $3.21 \mathrm{E}-04$ & $7.54 \mathrm{E}-04$ & $6.13 \mathrm{E}-03$ & $1.44 \mathrm{E}-02$ \\
$\begin{array}{l}\text { Ecotoxicity } \\
\begin{array}{l}\text { Resource/Fossil fuel } \\
\text { depletion }\end{array}\end{array}$ & CTUe & $4.60 \mathrm{E}-01$ & $1.18 \mathrm{E}-01$ & $8.77 \mathrm{E}+00$ & $2.26 \mathrm{E}+00$ \\
\hline
\end{tabular}

The life cycle inventory compiled in this study is based on Chinese literatures. This is expected since almost all the mining of ion adsorption clays occurs in China. Although there are many studies that report material/energy consumption and environmental emissions associated with in site leaching of ion adsorption clays, a complete inventory is in general not available in a single study. To make it worse, REE distribution and mining operation could vary significantly from site to site, and some of the studies may be out of date. Even with the low/high range presented, the numbers may not be representative for the current mining activities in China. Furthermore, there is illegal and unregulated REE extraction occurring, which constitutes a considerable share of the market (Yang et al., 2013), but material/energy consumption and environmental releases at these sites are largely unknown. The inventory and the resulted impact assessment reported here likely carry large uncertainties and have to be used with caution.

\section{Conclusion}

This study represents the first LCA effort on the production of REOs via in-situ leaching of ion adsorption clays in southern China. Material/energy flow and emission data are extracted from Chinese literature on mining activities carried out at different sites within the region. Ecoinvent 3.0 database and SimaPro 8.0 were used for inventory analysis. EPA TRACI and ILCD were used for impact assessment, with cumulative energy demand replacing fossil fuel usage. Given the large variance on material and energy flows reported for different mining sites, the results were calculated and presented as low and high estimates.

The estimates show that most environmental impact categories range from between $130 \%$ and $180 \%$ of the low estimate, with the exception of eutrophication which is approximately $900 \%$. In terms of the materials consumed, ammonium sulphate has the most significant influence across all impact categories. Oxalic acid also has significant contributions. Since citric acid was used as a surrogate for oxalic acid in this investigation, this represents an area where a clear understanding of environmental impacts associated with oxalic acid production would be beneficial. 
The results are compared to published studies on the bastnasite/monazite processing route for REOs. On the basis of $1 \mathrm{~kg}$ REO mixture, the environmental impact for the in-situ leaching of ion-adsorption clays is similar to the bastnasite/monazite route with regard to global warming and cumulative energy demand. However, in situ leaching tends to have much smaller impact in the category of acidification but significantly higher impact in the category of eutrophication. In addition, economic value based allocation is used to determine environmental impacts of individual REO. Since the content of high value HREEs is much higher in ion adsorption clay, individual REO from in situ leaching has lower environmental impacts across almost all categories considered. Given their unique geological features, ion-adsorption clays will continue to play a role in the production of REEs, especially HREEs. Results of this LCA study can be combined with previous studies to give a more accurate picture on the environmental profiles of REEs and REOs. This in turn will lead to better understanding on the environmental impacts of products incorporating REEs.

\section{Acknowledgments}

This work is supported by the Critical Materials Institute (CMI), an Energy Innovation Hub funded by the U.S. Department of Energy, Office of Energy Efficiency and Renewable Energy, Advanced Manufacturing Office. Any opinions, findings, conclusions, or recommendations expressed in this report are those of the authors and do not necessarily reflect the views of the U.S. Department of Energy.

\section{References}

Adachi, G. Y., Imanaka, N., \& Tamura, S. (2010). Research trends in rare earths: A preliminary analysis. Journal of Rare Earths, 28(6), 843-846.

Adibi, N., Lafhaj, Z., Gemechu, E. D., Sonnemann, G., \& Payet, J. (2014). Introducing a multicriteria indicator to better evaluate impacts of rare earth materials production and consumption in life cycle assessment. Journal of Rare Earths, 32(3), 288-292.

Althaus, H. J., Chudacoff, M., Hischier, R., Jungbluth, N., Osses, M., \& Primas, A. (2007). Life Cycle Inventories of Chemicals. Final report ecoinvent data v2. 0 No. 8. EMPA Dübendorf, Swiss Centre for Life Cycle Inventories, Dübendorf, CH. Online-Version under: www. ecoinvent. ch. 
Bao, Z., \& Zhao, Z. (2008). Geochemistry of mineralization with exchangeable REY in the weathering crusts of granitic rocks in South China. Ore Geology Reviews, 33(3), 519-535.

Bauer, D., Diamond, D., Li, J., Sandalow, D., Telleen, P., \& Wanner, B. (2010). US Department of Energy Critical Materials Strategy.

Binnemans, K., Jones, P.T., Blanpain, B., Van Geven, T., Yang, Y., Walton, A., \& Buchert, M. (2013). Recycling of rare earths: a critical review. Journal of Cleaner Production, 51, 1-22.

Bradsher, K. (2009). Earth-friendly elements, mined destructively. New York Times, A1.

Chakhmouradian, A. R., \& Wall, F. (2012). Rare earth elements: Minerals, mines, magnets (and more). Elements, 8(5), 333-340.

Chancerel, P.; Marwede, M.; Nissen, N.F.; Lang, K.-D. (2015), Estimating the quantities of critical metals embedded in ICT and consumer equipment, Resources, Conservation and Recycling, 98, 9-18.

Charles, N., Tuduri, J., Guyonnet, D., Melleton, J., \& Pourret, O. (2013). Rare earth elements in Europe and Greenland: a geological potential? An overview. In $12^{\text {th }}$ meeting of the Society of Geology Applied to Mineral Deposits (SGA), 12-15.

Chi, R. A., Zhou, Z., Xu, Z., Hu, Y., Zhu, G., \& Xu, S. (2003). Solution-chemistry analysis of ammonium bicarbonate consumption in rare-earth-element precipitation. Metallurgical and Materials Transactions B, 34(5), 611-617.

China Aluminum Corporation. (2014). Liutang Rare Earth Mine Environmental Impact Report. Chongzuo Rare Earth Development Co. Ltd.

Chinese Society of Rare Earth (CSRE): Annual report 2002.

$\mathrm{Du}, \mathrm{W}$. (2001). The impact of in-situ leaching on the natural environment of ion-type RE mine. Jiangxi Nonferrous Metals, 15(1), 41-44. (in Chinese).

Eggert, R. G., Carpenter, A. S., Freiman, S. W., Graedel, T. E., Meyer, D. A., McNulty, T. P., et al. (2008). Minerals, critical minerals and the US economy. US National Research Academies Press. Washington, DC. 
Ferella, F.; Innocenzi, V.; Maggiore, F. (2016), Oil refining spent catalysts: A review of possible recycling technologies, Resources, Conservation and Recycling, 108, 10-20.

Golev, A., Scott, M., Erskine, P. D., Ali, S. H., \& Ballantyne, G. R. (2014). Rare earths supply chains: Current status, constraints and opportunities. Resources Policy, 41, 52-59.

Greenfield, A.; Graedel, T.E. (2013), The omnivorous diet of modern technology, Resources, Conservation and Recycling, 74, 1-7.

Guinée, J. B. (2002). Handbook on life cycle assessment operational guide to the ISO standards. The international journal of life cycle assessment, 7(5), 311-313.

Gupta, C.K., \& Krishnamurthy, N. (2005). Extractive metallurgy of rare earths. CRC Press, Boca Raton, Florida.

Hellman, P. L., \& Duncan, R. K. (2014). Evaluation of rare earth element deposits. Applied Earth Science (Trans. Inst. Min. Metall. B), 123(2), 107-117.

Hurst, C. (2010). China's Rare Earth Elements Industry: What Can the West Learn?, Institute for the Analysis of Global Security. Washington DC.

ISO. (2006). 14040: Environmental Management-Life Cycle Assessment-Principles and Framework. London: British Standards Institution.

Jordens, A., Cheng, Y. P., \& Waters, K. E. (2013). A review of the beneficiation of rare earth element bearing minerals. Minerals Engineering, 41, 97-114.

Jun, T., Chi, R., \& Yin, J. Q. (2010). Leaching process of rare earths from weathered crust elution-deposited rare earth ore. Transactions of Nonferrous Metals Society of China, 20(5), 892896.

Jun, T., Jingqun, Y., Guohua, R., Mintao, J., \& Chi, R. (2011). Extraction of rare earths from the leach liquor of the weathered crust elution-deposited rare earth ore with non-precipitation. International Journal of Mineral Processing, 98(3), 125-131.

Koltun, P., \& Tharumarajah, A. (2014). Life cycle impact of rare earth elements. ISRN Metallurgy, 1-10. 
Kynicky, J., Smith, M. P., \& Xu, C. (2012). Diversity of rare earth deposits: the key example of China. Elements, 8(5), 361-367.

Li, Chun. (2011). The generalization and application of new Technology on lixiviating mineral at the original place for ionic rare earths. Nonferrous Metals Science and Engineering, 2(1), 63-67. (in Chinese).

Li, X. F., Chen, Z. B., \& Chen, Z. Q. (2014). Distribution and fractionation of rare earth elements in soil-water system and human blood and hair from a mining area in southwest Fujian Province, China. Environmental Earth Sciences, 72(9), 3599-3608.

Lianfeng, X. (1999). Impact of Rare earth Exploitation on Land Resources and Its Ecological Recovery.[J]. RURAL ECO-ENVIRONMENT, 1.

Liao, Z., He, W., Liu H. \& Wang, X. (2014). Quality assessment of geological environment of ion-absorbed rare-earth mine in Longnan County. Nonferrous Metals Science and Engineering, 6(4), 106-111. (in Chinese).

Luo, X., Weng, C., Xu, J., Ma, P., Tang, X., \& Chi, R. (2014). Research progress on and development trend of exploitation technique of ion-absorbed type rare earth ore. Metal Mine, 6, 83-90. (in Chinese).

Machacek, E.; Richter, J.L.; Habib, K.; Klossek, P. (2015), Recycling of rare earths from fluorescent lamps: Value analysis of closing-the-loop under demand and supply uncertainties, Resources, Conservation and Recycling, 104, 76-93.

Ministry of Environmental Protection of the People's Republic of China (MEP). (2011). Emission standards of pollutants from rare earths industry. GB 26451-2011. China Environmental Science Press. Beijing, China, 1-13 (in Chinese).

Ministry of Environmental Protection of the People's Republic of China (MEP). (2009). Explanation for the Compilation of Emission Standards of Pollutants from Rare Earths Industry (JE-99), 17-18.

Moldoveanu, G. A., \& Papangelakis, V. G. (2012). Recovery of rare earth elements adsorbed on clay minerals: I. Desorption mechanism. Hydrometallurgy, 117, 71-78. 
Navarro, J., \& Zhao, F. (2014). Life cycle assessment of the production of rare earth elements for energy applications: a review. Frontiers in Energy Research, 2, 45.

Nuss, P., \& Eckelman, M. J. (2014). Life cycle assessment of metals: a scientific synthesis. PloS one, 9(7), e101298.

Papangelakis, V. G., \& Moldoveanu, G. (2014). Recovery of rare earth elements from clay minerals. $1^{\text {st }}$ European Rare Earth Resources Conference. Milos, Greece. 191-202.

Riemenschneider, W., \& Tanifuji, M. (2011). Oxalic Acid. Ullmann's Encyclopedia of Industrial Chemistry. 25, 529-541.

Schüler, D., Buchert, M., Liu, R., Dittrich, S., \& Merz, C. (2011). Study on rare earths and their recycling. Öko-Institut eV Darmstadt.

Shi, F. (2009).Rare Earth Metallurgy Technology. Metallurgical Industry. Beijing,

Song, H.F., Hong, M., (2010a). The analysis and prediction of rare earth industry in China (I), Rare Earth, Information, No.2, 6-8 (in Chinese).

Song, H.F., Hong, M., (2010b). The analysis and prediction of rare earth industry in China (II), Rare Earth, Information, No.2, 8-12 (in Chinese).

Sprecher, B., Xiao, Y., Walton, A., Speight, J., Harris, R., Kleijn, R., et al. (2014). Life cycle inventory of the production of rare earths and the subsequent production of $\mathrm{NdFeB}$ rare earth permanent magnets. Environmental Science \& Technology, 48(7), 3951-3958.

State Environmental Protection Administration of China and General Administration of Quality Supervision IaQoC. Limits and measurement methods for exhaust pollutants from diesel engines of non-road mobile machinery (I, II) (2007). GB 20891-2007 (in Chinese).

Su, W., 2009. Economic and policy analysis of China's rare earth industry (in Chinese). China Financial and Economic Publishing House, Beijing.

Tang, X., \& Li, M. (1997). Monitoring of in-situ leaching stope of ion-absorbed rare earth mine. Mining Research and Development, 21(4), 10-12 (in Chinese).

Tse, P. K. (2011). China's rare-earth industry. US Department of the Interior, US Geological Survey. 
United States Geological Survey (USGS), (2008). Minerals commodity Summaries Rare Earths, January 2008.

United States Geological Survey (USGS). (2014). Mineral Commodity Summaries 2014. Government Printing Office: Washington, DC.

Walters, A., Lusty, P., \& Hill, A. (2011). Rare earth elements. Mineral Profile Series, British Geological Survey, United Kingdom

Wu, W. Y. (2005). Rare-earth metallurgy. Beijing: Chemical Industry Press. (in Chinese).

Wu, Y.F.; Yin, X.F.; Zhang, Q.J.; Wang, W.; Mu, X.Z. (2014), The recycling of rare earths from waste tricolor phosphors in fluorescent lamps: A review of processes and technologies, Resources, Conservation and Recycling, 88, 21-31.

Wübbeke, J. (2013). Rare earth elements in China: Policies and narratives of reinventing an industry. Resources Policy, 38(3), 384-394.

Xiao, Z. Z., Tang, X. Z., Wang, X. M., \& Li, J. X. (2003a). Study on in-situ leaching stope of deeply soleplate ion-absorbed rare earth (first). Industrial Minerals and Processing, 11, 16-18. (in Chinese).

Xiao, Z. Z., Tang, X. Z., Wang, X. M., \& Li, J. X. (2003b). Study on in-situ leaching stope of deeply soleplate ion-absorbed rare earth (second). Industrial Minerals and Processing, 12, 9-11. (in Chinese).

Yang, X., Lin, A., Li, X., Wu, Y., Zhou, W., \& Chen, Z. (2013). China's ion-adsorption rare earth resources, mining consequences and preservation. Environmental Development, 8, 131-136. (in Chinese)

Yu, Q., Qiu, D., Ma, R., \& Zhou, Z. (1990). The techniques for extraction of rare earths from the ionic type rare earth ores and their possible improvements. Mining and Metallurgical Engineering, 10(1), 42-45. (in Chinese).

Zaimes, G.G., Hubler, B.J., Wang, S. \& Khanna, V. (2015). Environmental life cycle perspective on rare earth oxide production. ACS Sustainable Chemistry \& Engineering, 3(2), 237-244. 
Zhao, J., Tang, X. Z., \& Wu, C. (2001). Status quo of mining and recovering technologies for ion-absorbed rare earth deposits in China. Yunnan metallurgy, 30(1), 11-14. (in Chinese).

Zhu, Q., Tian, C. S., Xiao, Z. J., \& Liu, Z. W. (2013). Research progress and developing trend of soil nitrogen in ion-type rare earth with in-situ leaching. Nonferrous Metals Engineering \& Research, 2, 40-43. (in Chinese).

Zhu, Y., Zhou, L., \& Li, Q. (2011). Water Pollution Prevention Method for In-Situ Leach Mining of Ion-Absorbed Rare-Earth Mineral. Nonferrous Metals, 6, 46-49. (in Chinese).

Zou, G. (2012). A comparative study of the different mining and separating technologies of ionabsorbed rare earth from the perspective of production costs. Nonferrous Metals Science and Engineering, 3(4), 55. (in Chinese).

Zou, G., Wu, Y., \& Dai, S. (2014). The impacts of ion-adsorption rare earth's production technologies on resource and environment. Nonferrous Metals Science and Engineering, 5(6), 112. (in Chinese). 